\title{
Floral biology and a pollinator effectiveness test of the diurnal floral visitors of Tabernaemontana undulata Vahl. (Apocynaceae) in the understory of Amazon Rainforest, Brazil
}

Thaysa Nogueira de Moura ${ }^{1,4}$, Antonio Carlos Webber ${ }^{2}$ and Liliane Noemia Melo Torres ${ }^{3}$

Recebido em 7/04/2009 Aceito em 12/04/2011

\section{RESUMO}

(Biologia floral e teste da efetividade de polinização dos visitantes florais diurnos de Tabernaemontana undulata Vahl. (Apocynaceae) no sub-bosque da Amazônia Central, Brasil). Neste estudo foi examinada a biologia floral, a efetividade da polinização, freqüência de visitas e abundância relativa dos visitantes florais diurnos de T. undulata (Apocynaceae) em duas populações localizadas em floresta primária e em uma área perturbada conectada à mata contínua. Suas flores hermafroditas apresentam um longo e estreito tubo floral. Anteras introrsas formam um cone logo acima da cabeça estigmática, onde o pólen é depositado. A cabeça estigmática apresenta três regiões funcionais, em um mecanismo que favorece a polinização cruzada. Nos censos de polinizadores conduzidos na floresta primária registraram-se apenas visitas de Eulaema bombiformis. Na área perturbada apenas Euglossa sp. realizou visitas às flores de T. undulata. Na área perturbada E. bombiformis preferiu forragear em flores ricas em pólen e néctar de duas espécies vizinhas em floração. Na floresta primária T. undulata foi a única arvoreta em flor no fim da estação seca. Não foram encontradas diferenças significativas com relação à freqüência de visitas e abundância relativa entre os visitantes florais diurnos em ambas as áreas. No experimento de efetividade da polinização dos visitantes florais, foi observada a produção de um único fruto após visita de E. bombiformis a uma flor. Devido ao complexo sistema reprodutivo de T. undulata, onde há baixa produção de frutos mesmo em condições naturais, uma medida indireta da efetividade do polinizador se faz necessária em um estágio posterior deste estudo a fim de esclarecer o papel desempenhado por essas espécies de abelhas na polinização de T. undulata.

Palavras-chave: Amazônia Central, Eulaema bombiformis, Euglossa, Polinização

\begin{abstract}
(Floral biology and a pollinator effectiveness test of the diurnal floral visitors of Tabernaemontana undulata Vahl. (Apocynaceae) in the understory of Amazon Rainforest, Brazil). In this paper we examined the floral biology, per-visit effectiveness, frequency of visits and relative abundance of the diurnal floral visitor taxa of T. undulata (Apocynaceae) at two populations located in the primary forest and in a disturbed area connected to the continuous forest. Its hermaphrodite flowers show a long and narrow floral tube and introrse anthers form a cone around the apex of the style head where the pollen is deposited. The stigmatic head has three functional regions, in a complex pollination mechanism favoring cross-pollination. In the pollinator censuses conducted in the primary forest population we registered Eulaema bombiformis. In the disturbed area Euglossa sp. was responsible for visits on $T$. undulata flowers. Eulaema bombiformis was not absent in the disturbed area, but preferred to forage on pollen and nectar-rich flowers of two neighboring flowering species. In the primary forest, T. undulata was the only flowering treelet at the end of the dry season. Significant differences were not observed regarding the frequency of visits and relative abundance among the diurnal flower visitors at both sites. In the per-visit effectiveness experiment among flower visitors, we observed one fruit produced after E. bombiformis' visits. Due to the complex breeding system of $T$. undulata in that it is characterized by very low fruit production even under natural conditions, an indirect measure of pollinator effectiveness is needed in at a future stage of this study in order to clarify the role of these bee species as pollinators of T. undulata.
\end{abstract}

Key words: Central Amazonia, Eulaema bombiformis, Euglossa, Pollination

\footnotetext{
Universidade Federal do Amazonas, Instituto de Natureza e Cultura, Campus Alto Solimões, Benjamin Constant, AM, Brazil

2 Universidade Federal do Amazonas, Instituto de Ciências Biológicas, Departamento de Biologia, Manaus, AM, Brazil

Centro Educacional Literatus, Manaus, AM, Brazil

4 Author for correspondence: thaysamoura@yahoo.com.br
} 


\section{Introduction}

There is a traditional notion that the evolution of floral diversity is based upon specialized interactions of plant species and pollinators, which led to the classification of flowering plants into pollination syndromes (Faegri \& Pijl 1979). However, many studies have subsequently shown that even plants which exhibit characteristics of one pollination syndrome may be visited by other organisms which may contribute in both positive and negative ways to pollination dynamics and ultimately fitness at some level (Spears 1983; Waser et al. 1996).

Ollerton (1996) pointed out an apparent paradox between the ecological processes and phylogenetic constraints as many species produce specialized flowers which receive a diverse range of flower visitors suggesting that among all the flower visitors of a plant species only a small proportion can effectively pollinate it. Although differences in relation to pollination ability among flower visitors are probably quite common in nature, they have been poorly studied (Ollerton 1996; Johnson \& Steiner 2000; Ollerton et al. 2007).

Simple lists of flower visitors received by a plant provide little useful information because there is no distinction between visitors and effective pollinators (Johnson \& Steiner 2000). Identifying the pollen vectors among the flower visitors represents an important requirement for any pollination system investigation (Waser et al. 1996; Johnson \& Steiner 2000; Sahli \& Conner 2006).

The main tropical Apocynaceae s.s. are characterized by a complex pollination mechanism favoring cross pollination. This may have evolved in order to attract insects with long, strong mouth parts able to access the nectar in the tubular flowers (Darrault \& Schlindwein 2005). Besides the complex floral morphology, the existence of secondary pollen presentation co-occurring with herkogamy (Lopes \& Machado 1999) and the recent report of functional dioecy in members of the family (Koch et al. 2002), also indicate a specialized pollination mechanism in Apocynaceae, preventing self pollination. The genus Tabernaemontana L. belongs to the subfamily Rauvolfioideae in the Apocynaceae s.s. (Simões et al. 2006) where information regarding the breeding system and pollination biology are scarce. Few registers on pollination biology for representatives of the genus have been made in Brazil, with the exception of Gottsberger \& Gottsberger (2006) for Tabernaemontana hystrix Steud. and T. solanifolia DC., both with nocturnal flowers and classified as moth-pollinated by the authors.

The Amazon Rainforest, the largest tropical forest in the world, harbors a striking richness of animals and plants species (Whitmore 1998). Plant-animal systems, as all other kinds of species interactions, are also a critical aspect of this biodiversity (Ollerton \& Cranmer 2002; Ollerton et al. 2006). Most plant species in this ecosystem, especially those from the understory, are dependent on biotic pollination (Janzen 1975). Nevertheless, basic data on pollination biology are limited, probably as a consequence of the various logistical difficulties imposed by the complex structure of tropical rainforests (Bawa 1990; Kay \& Schemske 2003; Ollerton et al. 2006).

To our knowledge there are no studies on Tabernaemontana undulata Vahl., an understory treelet found in the Central Amazonia rainforest. Despite the fact that its flowers show morphological features compatible with the moth-pollination syndrome, they are frequently visited by Euglossine bees at the same time as they emit a strong sweet floral scent and offer nectar in the morning. In this study we examine some aspects of the floral biology and breeding system of T. undulata, and the per-visit effectiveness, frequency of visits and relative abundance of its diurnal floral visitors (Euglossine bees) at two populations in Central Amazonia. Our main question is: Do the Euglossine bees contribute to the pollination of the moth-flowers of T. undulata?

\section{Material and methods}

\section{Study area}

The study was conducted at Fazenda Experimental da Universidade Federal do Amazonas (2० 38' 57,6"S; 60 3' $11^{\prime \prime} \mathrm{W}, 96 \mathrm{~m}$ altitude), located at $\mathrm{km} 38$ of the federal road BR-174, in Manaus, Amazonas, northern Brazil. The area has various vegetation types, from which primary rainforest represents the largest portion of the total area. The study site is characterized by a hot, wet climate with distinct rainy and dry seasons. The rainy season is from December to May and the dry season from June to November.

We investigated two Tabernaemontana undulata populations at two different areas (Site 1 and Site 2) $2 \mathrm{~km}$ from each other. Site 1 represents the primary, continuous forest where ten individuals were marked. Site 2 is located in a secondary vegetation area where a plantation of Brazil nuts (Bertholletia excelsa Humb. \& Ponpl.) was made almost 40 years ago after deforestation. The plantation was abandoned and the area is now re-connected to the continuous forest, showing a mix of late successional and primary forest species. We also marked ten individuals at Site 2 . The distance between individuals in the two populations ranges from $2-50 \mathrm{~m}$. We conducted additional observations at a third area (Site 3) in the primary forest distant one kilometer from Site 1 and almost $500 \mathrm{~m}$ from Site 2 in order to verify possible microspatial variation in relation to the flower visitors' identity.

\section{Data collection}

Observations were carried out on the morphology, size and longevity of flowers ( 11 flowers from 10 individuals) and time of anthesis. Location of the stigmatic area of the style head was determined by the peroxidase technique (Kearns \& Inouye 1993). Five isolated flowers (five individuals) were used to measure nectar volume during anthesis after com- 
pleting a pollinator census, with a micro-syringe, and sugar concentration, with a portable refractometer. Pollen viability was tested in 10 flowers ( 10 individuals) with acetocarmine (Radford et al. 1974). The number of ovules and pollen grains was determined from 10 floral buds. Compatibility system was tested by the fruit set resulting from spontaneous self pollination ( 40 flowers from 20 individuals) and hand self pollination (40 flowers from 20 individuals), following the methods described by Darrault \& Schlindwein (2005). Furthermore, 40 exposed flowers (20 individuals from the two populations) were marked to verify fruit set under natural conditions.

In order to investigate the role of Euglossine bees in $T$. undulata pollination, we conducted diurnal pollinator censuses at Sites 1, 2 and 3 between October 19 and November 14,2007 , covering the total $T$. undulata flowering season. We conducted 10 censuses (a total of 30 hours) at Site 1 and another 10 (30 hours) at Site 2 on alternate days. At Site 3, four additional censuses (a total of 12 hours) were undertaken along the flowering period. In order to standardize data for statistical analysis, we defined a standard daily census period from 9am to noon when visitation is concentrated. Additional observations of the flower visitors' activity were conducted sporadically along the day (10 hours) and we also made nocturnal observations twice at Sites 1 ( 4 hours) and 2 (4 hours). During each 3 h-census, we carefully watched the activity of flower visitors at one marked treelet, recording the total number of flowers visited and the total time spent in flowers by each visitor species. We then calculated the visitation rate as the average of the total number of flowers visited by each floral visitor species in each census divided by the total time of a census ( 3 hours). To test the pollinator effectiveness, we marked and isolated with pollinator exclusion bags (voile) two unopened flowers per plant in both Sites 1 and 2 populations $(\mathrm{N}=40) 1$ day before a pollinator effectiveness experiment. Next day, we exposed unvisited, first day flowers, to visits of a single pollinator species which were bagged after each census to verify posterior fruit set. Each marked treelet in both populations was censused once. We recorded the number of buds and open flowers of the marked treelets and quantified the fruit production of censused treelets at the two populations in order to obtain an indicator of pollination success under natural conditions.

A majority of the visitation sequences were recorded with a video camera and flower visitors were identified through these video observations, following the methods described by Kay \& Schemske (2003). Identification of all the flower visitors to species would have required collecting, which was not possible for video observations.

We performed the Mann-Whitney U Test for non parametric data using Systat 12. For statistical analyses, we considered significant results if $\mathrm{P} \leq 0.05$.

Voucher specimens were deposited in the Instituto Nacional de Pesquisas da Amazônia - INPA herbarium (T.N. Moura - 222.703).

\section{Results}

Flower morphology, flower biology and compatibility system

Tabernaemontana undulata is a treelet which grows in the understory of terra firme forest. Flowering occurs once in a year, at the end of the dry season from October to November. The treelets, including some individuals which were not marked for the pollinator censuses, produced between 45-78 floral buds and their inflorescences usually open four flowers a day, following the steady state pattern described by Gentry (1974).

The flowers are hermaphrodite, salverform, presenting a long $(\mathrm{N}=11$; mean $=29 \mathrm{~mm}$; range $=24-33)$ and narrow $(\mathrm{N}=11$; mean diameter $=3.2 \mathrm{~mm}$; range $=2.8-3.6)$ floral tube. The corolla tube is pale red-white and the lobes are white flushed with red. The stamens are inserted on the corolla tube and the sessile, introrse anthers form a cone around the apex of the style head, occupying the entire inner part of the flower tube. The anthers shed longitudinally their pollen grains onto the apex of the style head, forming a pollen chamber characteristic of the tribe Tabernaemontaneae. In accordance with Fallen (1986), the style head (Fig. 1) shows three functional regions: (1) an apical, sterile region where pollen is deposited (secondary pollen presentation), (2) a median region which produces a sticky substance, and (3) a lower receptive region beneath a basal membranous ring. Upon contact with $\mathrm{H}_{2} \mathrm{O}_{2}$ this lower region reacted by liberating oxygen.

The ovary is superior, containing 68 ovules on average $(\mathrm{N}=10$; range $=59-74)$. The number of pollen grains per flower was, on average, $3467(\mathrm{~N}=10$; range $=3030-3775)$. Pollen viability was ca. 99\%.

The flowers opened around 5am and last for one and a half day. Nectar is available after $8 \mathrm{am}$. Mean nectar volume was $3 \mu$ l. Sugar concentration varied from 16-23\%. Only first-day flowers have a sweet scent (personal observation) which is perceptible only at a very close distance. However, after $9 \mathrm{am}$ the floral fragrance intensified and we could perceive it ca. $1 \mathrm{~m}$ distant from the plant.

In the compatibility system experiment, both hand and spontaneous self-pollination tests resulted in a total failure of fruit production, suggesting that Tabernaemontana undulata is self-incompatible. From the 40 exposed flowers (control), none produced fruits under natural conditions.

\section{Pollinator censuses}

Site 1: In the understory of the primary forest, T. undulata is one of the very few species flowering at the end of the dry season. We found only two herbaceous species simultaneously flowering: Heliconia sp. (Heliconiaceae), which was visited by hummingbirds and Monotagma spicatum (J.B. Aublet) Macbride (Marantaceae) visited by an un- 


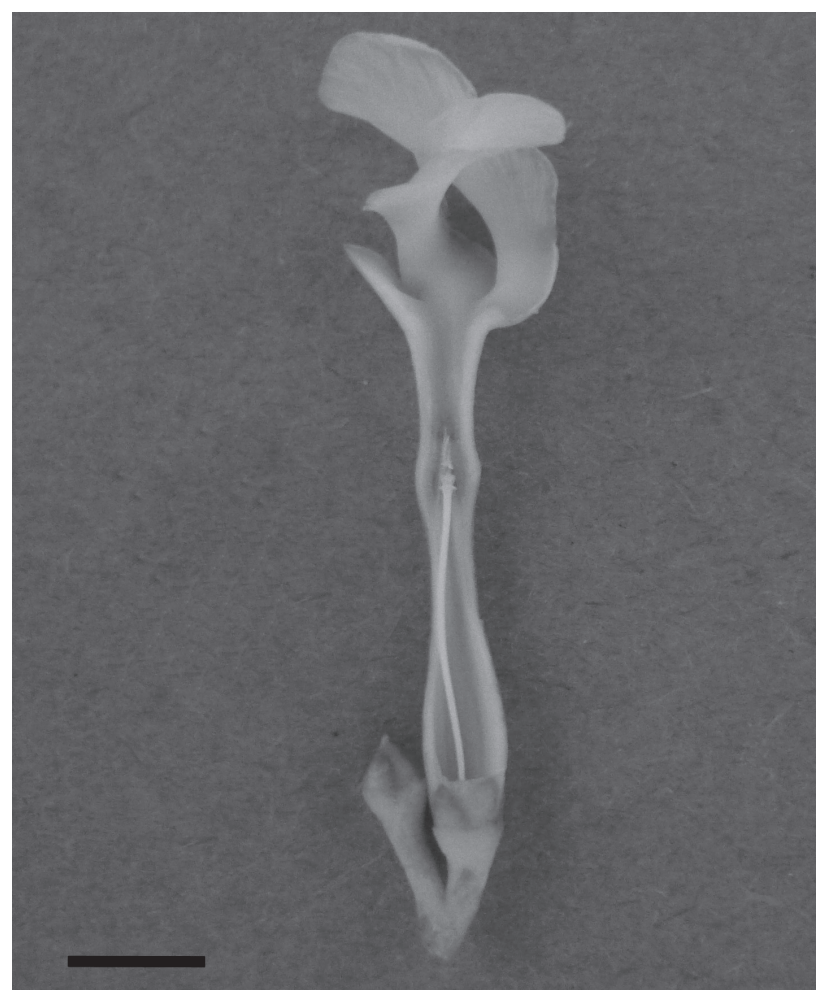

Figure. 1. Tabernaemontana undulata Vahl. (Apocynaceae) in Central Amazonia, Brazil. Longitudinal section of the floral tube showing the style with the stigmatic head.

identified bee. In the 10 censuses conducted, we registered Eulaema bombiformis Packard (1869) visiting T. undulata flowers at Site 1. On average, E. bombiformis visited twice (Tab. 1) each censused treelet and the interval between visits was 15-30 min. From the few E. bombiformis visits received by a plant, most are concentrated in the morning (9am-midday), coinciding with the time when nectar was fully available and the sweet floral odor intensified. After midday, E. bombiformis visited T. undulata flowers sporadically, but we never observed visits after $2 \mathrm{pm}$. After visiting all first-day flowers on the same plant, we often observed E. bombiformis visiting other T. undulata plants in sequence. Despite the fact that we did not mark the bees, we never saw two E. bombiformis individuals foraging simultaneously, which may indicate that a majority of visits were performed by a single bee individual. We also made nocturnal observations (4 hours) at Site 1, when no nocturnal flower visitors were registered.

Site 2: This disturbed area now connected to the continuous forest has late successional species growing together with some mature forest species. At the period of T. undulata flowering season, two arboreal species were simultaneously flowering at Site 2: the late successional species Bellucia cf. dichotoma Cogn. (Melastomataceae), which was in the flowering peak and the Brazil nut Bertholletia excelsa (Lecythidaceae), starting its flowering period. During all 10 censuses, we registered Euglossa sp. dominating the visits to T. undulata flowers. We also observed in just two censuses an unidentified butterfly species visiting two flowers per individual. Along each census, we observed Euglossa sp. performing a single visit on each censused treelet (Tab. 1), also visiting only firstday flowers. Similar to E. bombiformis behavior at Site 1, Euglossa sp. concentrated its visits in the morning (9ammidday), with rare visits between midday-2pm, which suggests that the sweet floral fragrance plays an important role in attracting T. undulata diurnal flower visitors. We registered that Euglossa sp. frequently visited only few opened flowers on the same plant and then moved to another T. undulata treelet. The fact that we could not observe E. bombiformis visiting T. undulata flowers does not mean that this bee species was absent at Site 2. On the contrary, before each census (7am-9am), we could observe E. bombiformis visiting frequently the pollenrich flowers of B. cf. dichotoma. Although we could not observe directly E. bombiformis visiting B. excelsa because of tree height $(30 \mathrm{~m})$, there is a great possibility since the Brazil nut species represents an important nectar source for Euglossini bees and depends on them as its pollinators. In nocturnal observations at Site 2 (4 hours), no nocturnal flower visitors were observed.

Site 3: In four additional censuses conducted in a primary forest area distant $500 \mathrm{~m}$ from Site 2, we registered E. bombiformis at T. undulata flowers. The floral visitor behavior was similar to that described for Site 1. In this area, we also found Heliconia sp. and Monotagma spicatum (J.B. Aublet) Macbride flowering.

\section{Frequency of visits and pollination effectiveness}

We did not find significant differences on visitation rates of E. bombiformis and Euglossa sp. (Tab. 1) between the two populations at Sites 1 and 2 (Mann-Whitney U Test: 45 , $\mathrm{df}=1, \mathrm{P}=0.70$ ). The number of visits performed by each pollinator taxa (Tab. 1) was not significantly different (Mann-Whitney U Test: $66, \mathrm{df}=1, \mathrm{P}=0.170$ ), as well as the number of opened flowers in the day when each treelet was censused (Tab. 1) in the two populations (Mann-Whitney U Test: 48 , $\mathrm{df}=1, \mathrm{P}=0.877)$.

In the per-visit effectiveness test, from 20 marked flowers visited by E. bombiformis at Site 1 population, we registered one fruit produced. At site 2, there was no fruit production. Whereas T. undulata seems to be self-incompatible and, in fact, shows complex morphology preventing selfpollination, we consider that any fruit produced by a treelet must be a consequence of the pollinators' visits.

We quantified the number of buds and fruit production under natural conditions on each censused treelet in both populations (Tab. 2). There was higher fruit production (Tab. 1) in Site 2 population compared to Site 1 (Mann-Whitney U Test: $15.5, \mathrm{df}=1, \mathrm{P}=0.008)$. 


\section{Discussion}

The arrangement of the flower parts in Tabernaemontana undulata makes autogamy difficult and thus favors cross pollination in this species (Fallen 1986). The floral structure ensures that in a single visit the flower visitor first deposits outcrossed pollen on the stigmatic surface and then transfers the self pollen. To self pollinate a flower, the flower visitor would have to visit the same flower at least twice in order to remove self pollen and then deposit it onto the style head. However, we never observed E. bombiformis and Euglossa sp. visiting the same flower consecutively.

Despite the fact that T. undulata pollination mechanism avoids self pollination, this does not prevent geitonogamy. The pollinator effectiveness test failure may be explained by at least two reasons: geitonogamy and a low fruit set pattern for this species. The deposition of self pollen onto the stigma of a self-incompatible species may interfere with the growth of pollen tubes from outcross pollination, resulting in a clogging effect. Observations of the foraging behavior of the flower visitors indicated that, while E. bombiformis visited all opened flowers of the same treelet before moving to another T. undulata individual, Euglossa sp. visited few opened flowers on the same plant and then moved to another T. undulata treelet. Differences in relation to the visitation pattern of the two bee species could have been responsible for the higher fruit production detected in Site 2 population, where Euglossa sp. was the unique flower visitor observed.

Darrault \& Schlindwein (2005) also considered that the best pollinator of Hancornia speciosa Gomez (Apocynaceae) would visit one or a few flowers of the same plant individual before switching to flowers of another treelet, avoiding geitonogamy in this way. However, the clogging effect through

Table 1. Visitation rates of the floral visitors of Tabernaemontana undulata Vahl. in Central Amazonia, Brazil, registered along 20 censuses (Sites 1 and 2) at Fazenda Experimental UFAM in 2007 (19 October - 14 November). Rates in bold represent the total number of visited flowers by each floral visitor species in each census divided by the total time of a census ( 3 hours). Total number of legitimate visits is represented in parenthesis under each rate. (F) number of opened flowers per individual plant in each census.

\begin{tabular}{|c|c|c|c|c|c|c|c|c|c|c|}
\hline \multirow[t]{2}{*}{ Floral visitor } & \multicolumn{10}{|c|}{ Site 1} \\
\hline & $1(4 \mathrm{~F})$ & $2(2 \mathrm{~F})$ & $3(7 F)$ & $4(3 F)$ & $5(3 F)$ & $6(2 F)$ & $7(3 F)$ & $8(2 \mathrm{~F})$ & $9(1 \mathrm{~F})$ & $10(5 F)$ \\
\hline \multirow[t]{3}{*}{ Eulaema bombiformis } & $2.6(4)$ & $0.6(1)$ & $2.3(8)$ & $1(1)$ & $1(1)$ & $0.6(2)$ & $1(1)$ & - & - & $1(3)$ \\
\hline & \multicolumn{10}{|c|}{ Site 2} \\
\hline & $1(7 \mathrm{~F})$ & $2(3 F)$ & $3(5 F)$ & $4(4 \mathrm{~F})$ & $5(5 F)$ & $6(2 F)$ & $7(2 \mathrm{~F})$ & $8(2 F)$ & $9(2 F)$ & $10(2 \mathrm{~F})$ \\
\hline Euglossa sp. & $2.3(1)$ & $1(1)$ & $1.6(1)$ & $1.3(1)$ & $1.6(1)$ & $0.6(1)$ & $0.6(1)$ & $2.3(1)$ & - & - \\
\hline
\end{tabular}

Table 2. The number of buds (NOF) on each censused treelet and number of fruits produced under natural conditions by all censused plants in the two populations of Tabernaemontana undulata Vahl. in Central Amazonia. There are no significant differences in the number of buds between the two populations (Mann-Whitney $\mathrm{U}$ Test: $35, \mathrm{df}=1, \mathrm{P}=0.256$ ). The fruit set in the two populations is significant different (Mann-Whitney $\mathrm{U}$ Test: 15.5 , $\mathrm{df}=1, \mathrm{P}=0.008$ ).

\begin{tabular}{|c|c|c|c|c|}
\hline \multirow[b]{2}{*}{ Censused plants } & \multicolumn{2}{|c|}{ SITE 1} & \multicolumn{2}{|c|}{ SITE 2} \\
\hline & N. of Buds & Fruit set & N. of buds & Fruit set \\
\hline 1 & 47 & 2 & 52 & 9 \\
\hline 2 & 22 & 0 & 49 & 5 \\
\hline 3 & 35 & 0 & 60 & 8 \\
\hline 4 & 60 & 2 & 43 & 7 \\
\hline 5 & 50 & 2 & 68 & 8 \\
\hline 6 & 30 & 0 & 37 & 2 \\
\hline 7 & 25 & 0 & 71 & 9 \\
\hline 8 & 70 & 15 & 30 & 5 \\
\hline 9 & 44 & 6 & 41 & 7 \\
\hline 10 & 32 & 0 & 39 & 5 \\
\hline
\end{tabular}


geitonogamy is unlikely to be the only reason for the very low fruit set observed in the pollination effectiveness test and under natural conditions. Low levels of fruit set are reported by a number of studies in Apocynaceae (Lopes \& Machado 1999 and references therein) which may represent a widespread feature for this family. Herrera (1991) and Lin \& Bernardello (1999) report very low fruit : flower ratios for Nerium oleander L. and Aspidosperma quebracho-blanco Schlecht. (Apocynaceae), respectively. They suggest that an overproduction of flowers in the two species could be explained in terms of increased pollinator attraction and pollen donation in order to ensure a small amount of fruit and seed set.

Euglossini bees are well-known for their trapline foraging on steady-state understory plants, being considered important long flight distance pollinators (Dressler 1982; Endress 1994; Borrell 2005). These bees show some flower constancy, visiting the same individual plants daily along their feeding route (Janzen 1971). Flowers of species of Apocynaceae s.s. are considered important nectar sources for Euglossine bees and, because they have long proboscides compatible with the floral morphology commonly found in this family, these bees are generally considered to be pollinators (Tostes et al. 2003).

The salverform flowers of $T$. undulata show some features which allow a classification into the moth-pollination syndrome such as flower color and presence of a narrow floral tube (Endress 1994). In fact, the observed difference in fruit set between the two populations may also be related to visits from nocturnal pollinators. However, the fact that flowers are open by the morning and that they emit an intense sweet floral scent, together with nectar availability at this time, indicate that diurnal flower visitors, especially long-tongued ones, may contribute at some level to T. undulata reproduction.

To test the per-visit effectiveness of the Euglossine bees we used a direct measure of pollinator effectiveness by measuring the fruit set in response to pollinator visits, especially because it requires fewer assumptions and gives clearer results (Spears 1983). Through this method, we observed that only E. bombiformis was able to transfer pollen and pollinate one flower. Such as result comes as surprising considering the fact that the two bee species have similar morphology and behavior. Due to the complex breeding system of T. undulata, with very low fruit production even under natural conditions, an indirect measure of pollinator effectiveness, such as the measure of the amount of pollen transferred to stigmas, would be very important at a future stage of the present study in order to clarify the role of these bee species as pollinators of T. undulata.

\section{Acknowledgements}

We thank Marco Antonio Mendonça and staff of the Fazenda Experimental da Universidade Federal do Amazo- nas for essential logistical support. We thank Mary Endress for sending us important bibliographies and for very useful discussions. Thanks also to Paulo Eugênio Oliveira, Milena Faria Vieira and Leandro Freitas for critical reading of the manuscript and the anonymous reviewers for their important suggestions. We thank Enrique Vetterli Nuesch and Charles Zartman for kindly improving our English. This study is part of the M.Sc. thesis of the first author (Conselho Nacional de Desenvolvimento Científico e Tecnológico - CNPq grant).

\section{References}

Bawa, K.S. 1990. Plant-pollinator interactions in tropical rain forests. Annual Review of Ecology and Systematics 21: 399-422.

Borrell, B.J. 2005. Long tongues and loose niches: evolution of Euglossini bees and their nectar flowers. Biotropica 37(4): 664-669.

Darrault, R.O. \& Schlindwein, C. 2005. Limited fruit production in Hancornia speciosa (Apocynaceae) and pollination by nocturnal and diurnal insects. Biotropica 37(3): 381-388.

Dressler, R.L. 1982. Biology of the orchid bees (Euglossini). Annual Review of Ecology and Systematics 13: 373-394.

Endress, P.K. 1994. Diversity and evolutionary biology of tropical flowers. Cambridge, Cambridge University Press.

Faegri, K. \& van Der Pijl, L. 1979. The principles of pollination ecology. Oxford, Pergamon Press.

Fallen, M.E. 1986. Floral structure in Apocynaceae: Morphological, functional and evolutionary aspects. Botanische Jahrbucher fur Systematik 106: 245-286.

Gentry, A.H. 1974. Flowering phenology and diversity in tropical Bignoniaceae. Biotropica 6: 64-68.

Gottsberger, G. \& Gottsberger, I. 2006. Life in the cerrado: a South American tropical seasonal vegetation. Vol. II. Ulm, Pollination and seed dispersal. Reta Verlag.

Herrera, J. 1991. The reproductive biology of a riparian Mediterranean shrub, Nerium oleander L. (Apocynaceae). Botanical Journal of the Linnean Society 106(2): 147-172.

Janzen, D.H. 1971. Euglossine bees as long distance pollinators of tropical plants. Science 171: 203-205.

Janzen, D.H. 1975. Ecology of plants in the tropics. Arnold, London.

Jonhson, S.D. \& Steiner, K.E. 2000. Generalization versus specialization in plant pollination systems. Tree 15(4): 140-143.

Kay, K.M. \& Schemske, D.W. 2003. Pollinator assemblages and visitation rates for 11 species of Neotropical Costus (Costaceae). Biotropica 35: 198-207.

Kearns, C.A. \& Inouye, D.W. 1993. Techniques for pollination biologists. Niwot, University Press.

Koch, I.; Bittrich, V. \& Kinoshita, L.S. 2002. Reproductive biology and functional aspects of the floral morphology of Rauvolfia sellowii Mull. Arg. (Apocynaceae; Rauvolfioideae) - a report of dioecy in Apocynaceae. Botanische Jahrbucher fur Systematik 124: 83-104.

Lin, S. \& Bernardello, G. 1999. Flower structure and reproductive biology in Aspidosperma quebracho-blanco (Apocynaceae), a tree pollinated by deceit. International Journal of Plant Sciences 160(5): 869-878.

Lopes, A. \& Machado, I.C. 1999. Pollination and reproductive biology of Rauvoulfia grandiflora (Apocynaceae): secondary pollen presentation, herkogamy and self-incompatibility. Plant Biology 1: 547-553.

Ollerton, J. 1996. Reconciling ecological processes with phylogenetic patterns: the apparent paradox of plant-pollinator systems. Journal of Ecology 84: 767-769.

Ollerton, J. \& Cranmer, L. 2002. Latitudinal trends in plant-pollinator interactions: are tropical plants more specialized? Oikos 98: 340-350.

Ollerton, J.; Johnson, S.D. \& Hingston, A.B. 2006. Geographical variation in diversity and specificity of pollination systems. Pp. 283-308. In: Waser, N.M.; Ollerton, J. (Eds). Plant-pollinator interactions: from specialization to generalization. Chicago, University Chicago Press. 
Ollerton, J.; Killick, A.; Lamborn, E.; Watts, S. \& Whiston, M. 2007. Multiple meanings and modes: on the many ways to be a generalist flower. Taxon 56(3): 717-728.

Radford, A.E.; Dickinson, W.C.; Massey, J.R. \& Bell, C.R. 1974. Vascular plant systematics. New York, Harper \& Row.

Sahli, H.F. \& Conner, J.K. 2006. Characterizing ecological generalization in plant-pollination systems. Oecologia 148: 365-372.

Simões, A.O.; Livshultz, T.; Conti, E. \& Endress, M.E. 2006. Phylogeny and systematics of the Rauvolfioideae (Apocynaceae) based molecular and morphological evidence. Annals of the Missouri Botanical Garden 94: 268-297.
Spears, E.E. 1983. A direct measure of pollinator effectiveness. Oecologia, 57: 196-199.

Tostes, R.B.; Vieira, M.F. \& Campos, L.A.O. 2003. Polinização de Peltastes peltatus (Vell.) Woodson (Apocynoideae, Apocynaceae) por abelhas euglossineas. Pp. 3-9. In: Melo, G.A.R. \& Alves-dos-Santos, I. (Eds). Apoidea Neotropica: Homenagem aos 90 anos de Jesus Santiago Moure. Criciuma, Editora UNESC.

Waser, N.M.; Chittka, L.; Price, M.V.; Williams, N.M. \& Ollerton, J. 1996. Generalization in pollination systems, and why it matters. Ecology 77(4): 1043-1060.

Whitmore, T.C. 1998. An introduction to tropical rainforests. Oxford, Oxford University Press. 